\title{
Papillary thyroid carcinoma in a patient with Turner syndrome treated with human growth hormone
}

\author{
Rak brodawkowaty tarczycy u pacjentki z zespołem Turnera leczonej hormonem wzrostu
}

\author{
${ }^{1} J o a n n a$ Bautembach-Minkowska, ${ }^{1}$ Dorota Birkholz-Walerzak, ${ }^{2}$ Andrzej Kędzia, \\ ${ }^{1}$ Małgorzata Myśliwiec
}

\author{
1Department of Paediatrics, Diabetology, and Endocrinology, Medical University of Gdansk, Poland \\ ${ }^{2}$ Department of Clinical Auxology, Poznan University of Medical Sciences, Poland
}

\begin{abstract}
Thyroid cancer is a rare pathology in childhood and adolescence, being responsible for 1.5-3\% of all carcinomas in this age group. Differentiated thyroid carcinoma is the most commonly found variant, especially papillary carcinoma of the thyroid (PCT). Currently available data support the hypothesis that growth hormone $(\mathrm{GH})$ as well as insulin-like growth factor 1 (IGF-1) can facilitate carcinogenesis. There is a confirmed role of the GH/IGF-1 axis in cancer progression as an initiator of tumorigenesis and neoplastic transformation, metastasis, and resistance to chemotherapy and radiotherapy. Presently, application of recombinant GH is an acceptable method to treat female patients with growth failure during the course of Turner syndrome (TS). This article reports the case of a fourteen-year-old female patient with Turner syndrome, Hashimoto thyroiditis, and papillary thyroid carcinoma diagnosed during $\mathrm{GH}$ treatment. The immunochemical analysis of tumour tissue in our patient revealed intensive brown reaction that labelled expression of the IGF-1R vs. traced reaction or its lack in normal thyroid tissue. A significant role is played by IGF-1 in the pathogenesis of invasion of thyroid cancer; however, this effect is complex, and how it works is not well established.
\end{abstract}

Key words:

Turner syndrome, papillary thyroid carcinoma, growth hormone therapy, insulin-like growth factor 1.

\section{Streszczenie}

Rak tarczycy jest rzadko rozpoznawany u dzieci i nastolatków i stanowi 1,5-3\% nowotworów w tej grupie wiekowej. Najczęściej mamy do czynienia ze zróżnicowanym rakiem tarczycy, głównie rakiem brodawkowatym. Obecnie leczenie hormonem wzrostu pacjentek z zespołem Turnera jest ogólnie akceptowaną metodą leczenia niskorosłości. Istniejące doniesienia popierają hipotezę, że zarówno hormon wzrostu, jak i duże stężenia insulinopodobnego czynnika wzrostu 1 (insulin-like growth factor 1 - IGF-1) mogą sprzyjać nowotworzeniu. Bierze sie pod uwagę rolę osi GH/IGF-1 w progresji procesu nowotworowego, jako inicjatora kancerogenezy, przerzutów nowotworowych, oporności na chemioterapię i radioterapię oraz transformację nowotworową. W pracy przedstawiono pacjentkę z zespołem Turnera i chorobą Hashimoto, u której podczas leczenia rekombinowanym hormonem wzrostu rozpoznano raka brodawkowatego tarczycy. Badanie immunohistochemiczne tkanki nowotworowej u pacjentki wykazało intensywną reakcję wskazującą na obecność receptorów dla IGF-1 oraz bardzo słabą reakcję lub jej brak w zdrowej tkance tarczycy. Dotychczasowe doniesienia wskazują na bardzo ważną rolę IGF-1 w patogenezie i inwazyjności nowotworów złośliwych tarczycy. Jest ona złożona i jeszcze nie do końca poznana.

\section{Słowa kluczowe:}

zespół Turnera, rak brodawkowaty tarczycy, leczenie hormonem wzrostu, insulinopodobny czynnik wzrostu 1. 


\section{Introduction}

Treatment with growth hormone $(\mathrm{GH})$ in adolescent patients was approved by the US Food and Drug Administration (FDA) in 1985 [1]. In studies performed in children treated with recombinant human growth hormone $(\mathrm{rGH})$, an increased risk of carcinogenesis has been observed only in patients treated because of previous cancer diagnosis, particularly in those individuals subjected to radiotherapy [2]. Nonetheless, currently available data support the hypothesis that growth hormone $(\mathrm{GH})$ as well as insulin like growth factor 1 (IGF-1) can facilitate carcinogenesis $[3,4]$.

Presently, application of recombinant $\mathrm{GH}$ is an acceptable method to treat female patients with growth failure during course of Turner syndrome (TS). Turner syndrome is the most frequent chromosomal aberration in women, with a calculated incidence rate of 1:2000 - 1:2500 of all living, white, female newborns [5]. In the case of untreated girls with TS, the major issue is mean permanent height, which is approximately $20 \mathrm{~cm}$ less than the average height of adult women in certain populations [6]. The important condition for success is application of double doses compared to substitute therapy in pituitary gland failure (SNP) - starting at $0.33 \mathrm{mg} / \mathrm{kg} /$ week to $0.47 \mathrm{mg} / \mathrm{kg} /$ week when going further with the therapy [7].

In this report, we presented a patient with TS and Hashimoto thyroiditis, who was diagnosed with papillary thyroid cancer during recombinant human GH therapy. Thyroid cancer is the most common endocrine cancer, with incidence of $1.0-1.5 \%$ of all malignant cancers in children. Until now, increased risk of this type of cancer has not been reported in patients with TS.

\section{Case description}

A fourteen-year-old female patient was TS diagnosed during infancy (karyotype 45X). Since early childhood, the patient has been under care of a nephrology clinic due to the seconddegree bladder-urethral reflux, agenesis of the right kidney, and chronic recurrence of urinary tract infections. At the age of eight years, hypothyroidism was diagnosed during a course of Hashimoto thyroiditis - thyroid stimulating hormone (TSH) $9.12 \mu \mathrm{U} / \mathrm{ml}$ (0.35-4.92), free thyroxine (free T4) $8.9 \mathrm{pmol} / \mathrm{l}$ (9.1-21), antithyroid peroxidase antibodies (anty-TPO) $432.42 \mathrm{IU} / \mathrm{ml}[<115]$. Therefore, L-thyroxin treatment was initiated with modified doses according to hormonal results in order to keep the patient in euthyreosis, finally reaching $75 \mu \mathrm{g} / \mathrm{d}$. Family history towards thyroid disorders and ionising radiation was negative. At the age of nine years and two months recombinant human $\mathrm{GH}$ in a dose of $0.33-0.047 \mathrm{mg} / \mathrm{kg} /$ day was introduced with a very good response of acceleration of growth. In the beginning, Genotropin was used and then Omnitrope. In addition, the $\mathrm{GH}$ dose was correlated with the levels of IGF-1 and insulin like growth factor binding protein 3 (IGFBP-3) in serum.

At 13 years of age, oestrogen therapy was initiated with low doses of oestradiol $1 \times 6.25 \mu \mathrm{g} / \mathrm{d}$ (Oesclim 25, BGP Products).
The oestradiol dose was continuously increased during a year, reaching $25 \mu \mathrm{g} / \mathrm{d}$.

Due to co-existing Hashimoto disease, USG examination of the thyroid gland was routinely performed every 6 to 12 months. During the exam, in October 2012 (at the age of 13 years and 11 months) a hypoechogenic lesion was seen in the right lobe of the thyroid gland $(5.8 \times 5.3 \times 5.7 \mathrm{~mm})$ without significantly visible vascularisation. In addition, three normal lymph nodules were visible near the superior poles of both thyroid lobes. Therefore, the next control USG examination was recommended in three months and GH therapy was stopped because of this unclear lesion in the USG exam. In that moment, IGF-1 and IGFBP-3 levels were in the normal range for this age with clinical and biochemical symptoms of euthyroidism (IGF-1 - $461 \mathrm{ng} / \mathrm{ml}$ [220-972], IGFBP-3 - 8.04 ng/ ml [3.3-10], TSH - $3.13 \mu \mathrm{U} / \mathrm{ml}$ [0.35-4.92], and free T4 - $15.3 \mathrm{pmol} / \mathrm{l}$ [9.1-21]). In December 2012, the USG examination was repeated; the previously described lesion in the right lobe of thyroid gland was minimally larger $(6.6 \times 6.1 \times 6.0 \mathrm{~mm})$ and tiny vasculature was seen on the border. The elasticity imaging showed a very stiff mass. In January 2013 (patient's age 14 years and 2 months) fine needle biopsy was performed and the cytological exam revealed a structure of papillary thyroid cancer (microcarcinoma papillare glandulae thyreoideae). The patient was immediately qualified for surgery - total thyroidectomy with lymphadenectomy, including removal of central lymph nodules of the neck and about thyroid isthmus and both lobes. Also, the histopathology of the surgically removed tissue revealed a structure of classical papillary thyroid cancer, and tiny isolated neoplastic cells were observed about basic pathologic lesion. Importantly, cancerous inflammation did not cross behind the capsule of the gland. In addition, the stroma of the right thyroid lobe was characterised by colloidal goitre and multifocal reactive lymphoplasia. The left thyroid lobe, which was sent separately for evaluation, was also characterised by colloidal goitre and multifocal reactive lymphoplasia but was free from cancerous tissue. central lymph nodules of neck and about thyroid isthmus, and the left lobe were submitted for evaluation, and were found to be metastasis free (pT1a, N0, Mx).

After surgery, biochemical assays revealed adequate stimulation of TSH (104.41 ulU/ml [0.35-4.94]), thyroglobulin concentration below $1 \mathrm{ng} / \mathrm{ml}$, normal level of thyroid thyroglobulin antibodies (anti-Tg $23.42 \mathrm{IU} / \mathrm{ml}[<115]$ ), normal ionised calcium level (1.16 mmol/l [1.05-1.30]), and normal concentration of parathormone in serum (PTH) 87.00 pg/ml [16.00-87.00]. In the scintigraphic exam with ${ }^{131} \mathrm{~J}$ there was a visible concentration of tracer in thyroid remnants of the right, left, and pyramidal lobes; however, pathological concentration of radioactivity was not observed. Therefore, according to the primary process of the neoplastic disease and additional results, the performed treatment was accepted as completed, and there was no recommendation for further therapy using ${ }^{131} \mathrm{~J}$, according to Polish Endocrine Society recommendations from 2010 [8].

Presently, the patient remains under the control of the Department of Nuclear Medicine and Oncological Endocrinology in the Centre of Oncology, Gliwice, Poland and the Department 
of Paediatric Endocrinology of the Medical University of Gdansk, Poland. In addition, the function of parathyroid glands is normal, and the patient is being treated with suppressed doses of L-thyroxin. We have been continuing hormonal replacement therapy with oestrogen and progesterone. The results of controlled imaging exams and laboratory assays are normal, and the patient has been in continuous and total clinical remission of neoplastic disease

The control USG exam does not show any changes in thyroid remnant. Laboratory exams revealed: anti-Tg $2.24 \mathrm{IU} / \mathrm{ml}$ $[<115], \mathrm{TSH}(0.15 \mu \mathrm{lU} / \mathrm{ml}$ [0.35-4.94]), and free T4 $20.9 \mathrm{pmol} / \mathrm{l}$ [9.1-21]. Presently, height and body weight are within the average values for this population: height: $164 \mathrm{~cm}$ (50c), body mass: 58 kg (50c) (Fig. 1). The percentile graphs for Polish children from 2010 were used for evaluation [9].

\section{Evaluation of the insulin-like growth factor 1 receptor presence in tumour cells}

Insulin-like growth factor 1 receptor expression in papillary carcinoma cells from the patient was studied by immunochemistry. Polyclonal antibody against human IGF-1 receptor (Gene tex) was used in 1:150 dilution. For staining the REAL TM (real time), the EnVision TM Detection System Peroxidase/DAB (Dako Poland) was used. Immunochemical analysis of tumour tissue in our patient revealed intensive brown reaction that labelled expression of the IGFIR vs. traced reaction or its lack in normal thyroid tissue (Fig. 2, 3).

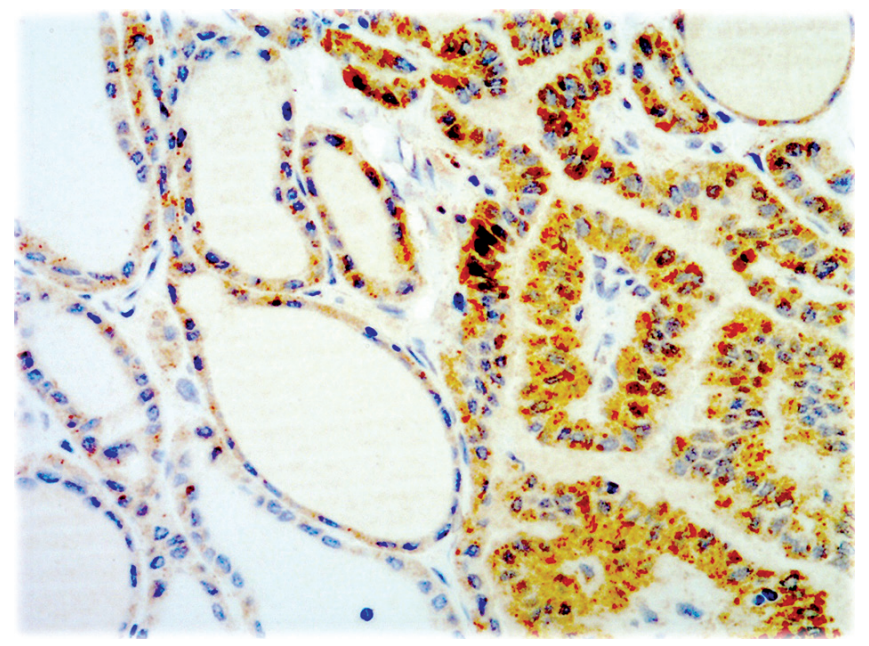

Figure 2. The immunochemical analysis of tumor tissue in our patient revealed intensive brown reaction that labeled expression of the IGFIR vs. traced reaction or its lack in normal thyroid tissue. Magnification $100 \times$

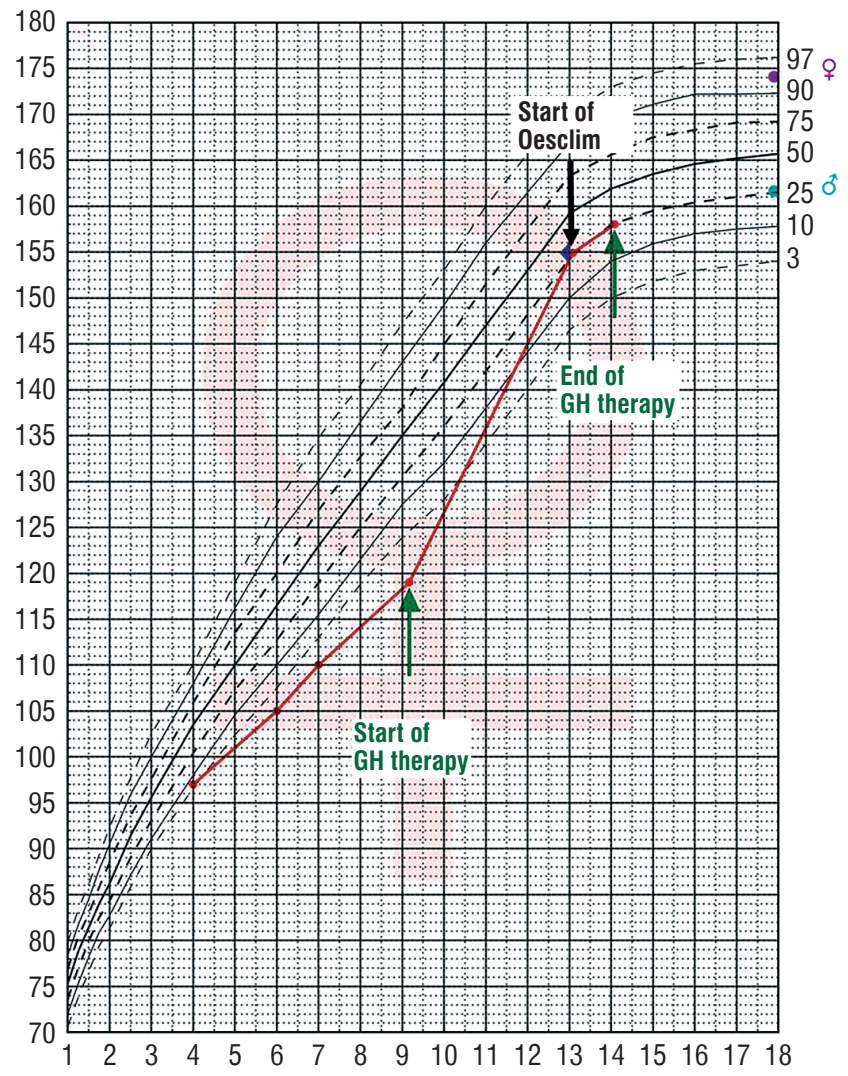

Figure 1. The percentile graph for patient S.W.

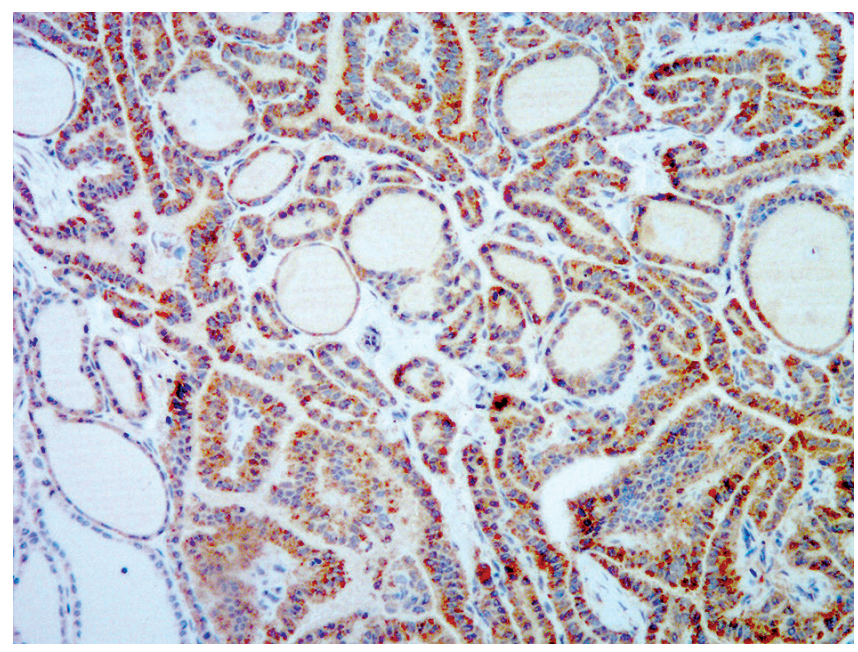

Figure 3. The immunochemical analysis of tumor tissue in our patient revealed intensive brown reaction that labeled expression of the IGFIR vs. traced reaction or its lack in normal thyroid tissue. Magnification $50 \times$ 


\section{Discussion}

The risk factors for thyroid cancer include: iodine deficiency, ionising radiation, sex, age, protooncogenes, hormones, and growth factors. All of them can change the biology of cancer. For example, iodine deficiency enhances secretion of thyrotropin (TSH), which, together with growth factors. i.e. epidermal growth factor (EGF) and IGF-1, may express the mitogenic effect on normal follicular cells [10].

Presented here, the case of the patient with TS, who was diagnosed with papillary thyroid cancer during GH treatment, is the third published case of PTC among girls with TS. Two previous cases were described by Cabanas et al. in 2005 [11].

However, it is difficult to prove that the papillary thyroid cancer diagnosed in our patient is linked to previously continued treatment with $\mathrm{GH}$ and oestrogens as well as autoimmunologic thyroid inflammation or chromosomal aberration previously diagnosed.

Theoretically, the risk of cancer development in a patient cohort with TS may be linked to lack of one copy of a gene or several genes located on chromosome X, which physiologically avoid inactivation during early embryogenesis [12]. During the course of TS, it may lead to expression of only one allele of these genes, whereas the expression is for both alleles in healthy women with 46,XX (physiological) karyotype [13]. There are many genes on chromosome $X$ that are linked to oncogenesis. Loss of chromosome $X$ or its fragments has been reported in the course of many cancers, e.g. meningioma, prostate cancer, and melanoma [13]. Described loss of fragments of chromosome $X$ suggest a presence on this chromosome of one or more suppressor genes or genes coding proteins involved in DNA repair, mutations of which may be linked to the pathogenesis of cancer [14].

Patients with TS autoimmunological disorders are often observed, i.e. juvenile autoimmune thyroiditis (JAT), Addison's disease, albinism, and alopecia [15]. However, the link between autoimmune thyroiditis disease and thyroid cancer is controversial. Cytological analyses do not confirm this link, although most studies containing surgical data prove a high frequency of tumours among patients with autoimmune thyroiditis. Differences in patient selection contributed to this variability that was associated with geographic and ethnic diversity in the prevalence of autoimmune thyroiditis and thyroid cancer [15]. Juvenile autoimmune thyroiditis has also been described as a protective factor $[16,17]$.

Generally, GH treatment in patients with TS is accepted in the world; however, the issue of the safety of this type of treatment was raised by Bolar et al. [18]. The authors analysed data from 5220 patients with TS, who had been treated with recombinant human $\mathrm{GH}$ during the preceding 20 years. While this retrospective study indicated that treatment with $\mathrm{GH}$ in this group of patients is safe, the risk of cancer in patients with TS during $\mathrm{GH}$ therapy seems to be similar to that seen in the rest of the population of children treated with recombinant $\mathrm{GH}$. The frequency of diagnosis of new cases of cancer in this group of patients was $0.11 \%$, compared with $0.06 \%$ in the group of children without genetic anomalies [18]. Large, retrospective studies comparing cytogenetic results and registry of data regarding registry of cancer morbidity, which analysed all together 5400 women with TS, showed only some increase in the risk of carcinogenesis in this patient cohort. It was noted for melanoma and various cancers of the Central Nervous System, but mainly meningioma. [19]. Larizza et al. retrospectively evaluated 87 TS women. Follow-up included periodic ultrasound of the neck, abdominal and pelvic organs, dermatologic evaluation, and faecal occult blood test. Karyotype was 45,X in 46 patients. During follow-up, 63 girls were treated with growth hormone, 65 with oestroprogestin replacement therapy and 20 with L-thyroxine. Autoimmune diseases were present in 29 TS. A total of 17 neoplasms in 14 out of 87 patients were found. Correlation among karyotypes, used therapy, coexisting autoimmune disorders, and incidence of cancer was not confirmed [20].

It is also not completely proven that hormonal therapy with $\mathrm{GH}$ can be linked to cancer growth in children with monogenetic disorders with their known predisposition to cancer, i.e. neurofibromatosis, Noonan syndrome, and Fanconi syndrome [21]. In addition, several reports have been published about endometrial cancer incidence in women with TS, which are probably linked to wrongly performed hormonal replacement therapy rather than directly being linked to TS [22]. Further studies are needed to define the overall risk for neoplasia and to determine the role of the loss of the X-chromosome and hormonal. Nonetheless, many publications have confirmed the safety of using recombinant $\mathrm{GH}$ in children. The report of the Paediatric Endocrine Society Drug and Therapeutics Committee from 2015 confirmed the safety of $\mathrm{GH}$ treatment in children [23].

On the other hand, analysis of several publications provides data confirming the role of IGF-I in carcinogenesis and development of malignant cancers. This growth factor impacts initiation as well as progression of cancer [24, 25]. Finally, IGF-1, in addition to the previously-mentioned endocrine effect on cancer progression, is directly secreted by cancerous cells and acts locally by auto- and paracrine effects [26].

It was showed that expression of insulin-like growth factor 1 receptor (IGF-1R) is increased in many types of cancer, and this effect plays a significant role in carcinogenesis [26]. The binding of IGF-1 to its receptor stimulates cell proliferation and inhibits apoptosis. Furthermore, activation of the IGF-1R intrinsic tyrosine kinase initiates phosphorylation of many intracellular proteins, which causes the mitogenic effect. Expression of the IGF-1R is regulated by growth factors - IGF-1, plateletderived growth factor (PDGF), epidermal growth factor (EGF), and fibroblast growth factor (FGF) as well as steroid hormones $[27,28]$. Inclusion of oestrogen treatment in our patient could also induce elevated levels of IGF-1 in serum and, consequently, cancer stimulation.

In in vitro experiments, it was confirmed that growth factors are actual cytokines with regulatory properties towards proliferation of follicular thyroid cells. There is a positive correlation between IGF-1 concentration and risk of thyroid cancer. In a paper published in 1989, Minuto et al. concluded that IGF-1 is involved in proliferation of thyroid cells through its auto- and 
paracrine effects [29]. Takahashi et al. showed, using immunochemical techniques, that the source of IGF-1 in growing thyroid gland is follicular cells [30]. Finally, Yashiro et al. showed significant elevation in the concentration of IGFBP3 in cells of papillary and medullary thyroid cancers [31]. Consequently, Lewiński et al. showed that IGF-1 has a stimulatory effect on expression of its own gene in papillary, medullary, and anaplastic thyroid cancers [32].

\section{Conclusions}

In summary, there is evidently a complex of many coexisting factors facilitating development of PTC in our patient, including high doses of $\mathrm{GH}$ used to improve definite growth,

\section{References}

1. Blizzard RM. History of growth hormone therapy. Indian J Pediatr 2012; 79: 87-91. doi: 10.1007/s12098-011-0609-4

2. Raman S, Grimberg A, Waguespack SG, et al. Risk of Neoplasia in Pediatric Patients Receiving Growth Hormone Therapy - A Report From the Pediatric Endocrine Society Drug and Therapeutics Committee. J Clin Endocrinol Metab 2015; 100: 2192-2203. doi: 10.1210/jc.2015-1002

3. Swerdlow AJ, Reddingius RE, Higgins CD, et al. Growth hormone treatment of children with brain tumors and risk of tumor recurrence. J Clin Endocrinol Metab 2000; 85: 4444-4449. doi: 10.1210/ jcem.85.12.7044

4. Pekic S, Popovic V. Management of endocrine disease: GH therapy and cancer risk in hypopituitarism: what we know from human studies. Eur J Endocrinol 2013; 169: R89-R97. doi: 10.1530/EJE-13-0389

5. Sybert VP, McCauley E. Turner's syndrome. N Engl J Med 2004; 351: 1227-1238. doi: 10.1056/NEJMra030360

6. Doswell BH, Visootsak J, Brady AN, et al. Turner syndrome: an update and review for the primary pediatrician. Clin Pediatr (Phila) 2006; 45: 301-313. doi: 10.1177/000992280604500402

7. Hilczer M, Lewiński A. Wskazania do leczenia hormonem wzrostu u dzieci i dorostych. Przegl Pediatr 2004; 34: 170-175.

8. Polska Grupa ds. Nowotworów Endokrynnych Jarząb B, Sporny S, Lange D, Włoch J, et al. Diagnostyka i leczenie raka tarczycy rekomendacje polskie. Endokrynol Pol 2010; 61: 518-568.

9. Kułaga Z, Litwin M, Tkaczyk M, et al. Polish 2010 growth references for school-aged children and adolescents. Eur J Pediatr 2011; 170: 599-609. doi: 10.1007/s00431-010-1329-x

10. Gabalec F, Srbova L, Nova M, et al. Impact of Hashimoto's thyroiditis, TSH levels, and anti-thyroid antibody positivity on differentiated thyroid carcinoma incidence. Endokrynol Pol 2016; 67: 48-53. doi: 10.5603/EP.a2016.0022

11. Cabanas P, García-Caballero T, Barreiro J, et al. Papillary thyroid carcinoma after recombinant GH therapy for Turner syndrome. Eur J Endocrinol 2005; 153: 499-502. doi: 10.1530/eje.1.01988

12. Swerdlow AJ, Hermon C, Jacobs PA, et al. Mortality and cancer incidence in persons with numerical sex chromosome abnormali- accompanied by an autoimmune disorder of thyroid and oestrogen substitute therapy. Based on current publications, there is a significant role of IGF-1 in the pathogenesis of invasion of thyroid cancer; however, this effect is complex and its workings are not well established. Further studies are also needed to define the overall risk for neoplasia, and to determine the role of the loss of the X-chromosome and hormonal. In our opinion our results raise the possibility that, under some circumstances, GH treatment may have effects unknown to us. Continued follow-up of these children is imperative. At the moment, in accordance with clinical practise guidelines for the care of girls and women with Turner syndrome: proceedings from the 2016 Cincinnati International Turner Syndrome Meeting, the thyroid gland is, on ultrasound, not different from that seen in the general population [33].

ties: a cohort study. Ann Hum Genet 2001; 65 (Pt 2): 177-188. doi: 10.1017/S0003480001008569

13. Brown CJ, Greally JM. A stain upon the silence: genes escaping $X$ inactivation. Trends Genet 2003; 19: 432-438. doi: 10.1016/S01689525(03)00177-X

14. Hasle H, Olsen JH, Nielsen J, et al. Occurrence of cancer in women with Turner syndrome. Br J Cancer 1996; 73: 1156-1159.

15. Chen YK, Lin CL, Cheng FT, et al. Cancer risk in patients with Hashimoto's thyroiditis: a nationwide cohort study. $\mathrm{Br} \mathrm{J}$ Cancer 2013; 109: 2496-2501. doi: 10.1038/bjc.2013.597

16. Corrias A, Cassio A, Weber G, et al. Thyroid nodules and cancer in children and adolescents affected by autoimmune thyroiditis. Arch Pediatr Adolesc Med 2008; 162: 526-531. doi: 10.1001/archpedi.162.6.526

17. Loh KC, Greenspan FS, Dong F, et al. Influence of lymphocytic thyroiditis on the prognostic outcome of patients with papillary thyroid carcinoma. J Clin Endocrinol Metab 1999; 84: 458-463. doi: 10.1210/jcem.84.2.5443

18. Bolar K, Hoffman AR, Maneatis T, et al. Long-term safety of recombinant human growth hormone in turner syndrome. J Clin Endocrinol Metab 2008; 3: 344-351. doi: 10.1210/jc.2007-1723

19. Ji J, Zöller B, Sundquist J, et al. Risk of solid tumors and hematological malignancy in persons with Turner and Klinefelter syndromes: A national cohort study. Int J Cancer 2016; 139: 754-758 doi: 10.1002/ijc.30126

20. Larizza D, Albanesi M, De Silvestri A, et al. Neoplasia in Turner syndrome. The importance of clinical and screening practices during follow-up. Eur J Med Genet 2016; 59: 269-273. doi: 10.1016/j. ejmg.2016.03.005

21. Ogilvy-Stuart AL, Gleeson H. Cancer risk following growth hormone use in childhood: implications for current practice. Drug Saf 2004; 27: 369-382. doi: 10.2165/00002018-200427060-00002

22. Hasle H, Olsen JH, Nielsen J, et al. Occurrence of cancer in women with Turner syndrome. Br J Cancer 1996; 73: 1156-1159.

23. Raman S, Grimberg A, Waguespack SG, et al. Risk of Neoplasia in Pediatric Patients Receiving Growth Hormone Therapy - A Report From the Pediatric Endocrine Society Drug and Therapeutics Committee. J Clin Endocrinol Metab 2015; 100: 2192-2203. doi: 10.1210/jc.2015-1002 
24. Khandwala HM, McCutcheon IE, Flyvbjerg A, et al. The effects of insulinlike growth factors on tumorigenesis and neoplastic growth. Endocr Rev 2000; 21: 215-244. doi: 10.1210/edrv.21.3.0399

25. Grimberg A, Cohen P. Role of insulin like growth factors and their binding proteins in growth control and carcinogenesis. J Cell Physiol 2000; 183: 1-9. doi: 10.1002/(SICI)1097-4652(200004)183:1<1::AIDJCP1>3.0.CO;2-J

26. Barnes BB, Chang-Claude J, Flesch-Janys D, et al. Cancer risk factors associated with insulin-like growth factor (IGF)-I and IGFbinding protein-3 levels in healthy women: effect modification by menopausal status. Cancer Causes Control 2009; 20: 1985-1996. doi: 10.1007/s10552-009-9393-0

27. Pollak MN, Schernhammer ES, Hankinson SE. Insulin-like growth factors and neoplasia. Nat Rev Cancer 2004; 4: 505-518. doi: $10.1038 / \mathrm{nrc1387}$

28. Pollak $M$. The insulin and insulin-like growth factor receptor family in neoplasia: an update. Nat Rev Cancer 2012; 12: 159-169. doi: 10.1038/nrc3215

29. Minuto F, Barreca A, Del Monte P, et al. Immunoreactive insulin-like growth factor I (IGF-I) and IGF-I-binding protein content in human thyroid tissue. J Clin Endocrinol Metab 1989; 68: 621-626. doi: 10.1210/jcem-68-3-621

30. Takahashi MH, Thomas GA, Williams ED. Evidence for mutual interdependence of epithelium and stromal lymphoid cells in a subset of papillary carcinomas. Br J Cancer 1995; 72: 813-817.

31. Yashiro T, Ohba $Y$, Murakami $H$, et al. Expression of insulin-like growth factor receptors in primary human thyroid neoplasms. Acta Endocrinol (Copenh) 1989; 121: 112-120.

32. Lewiński A, Marcinkowska M, Brzeziańska E, et al. Expression of insulin-like growth factor I (IGF-I) gene and of genes for IGF-binding proteins 1, 2, 3, 4 (IGFBP-1-IGFBP-4) in non-neoplastic human thyroid cells and in certain human thyroid cancers. Effect of exogenous IGF-I on this expression. Endocr Res 2004; 30: 47-59.

33. Gravholt $\mathrm{CH}$, Andersen NH, Conway GS, et al. Clinical practice guidelines for the care of girls and women with Turner syndrome: proceedings from the 2016 Cincinnati International Turner Syndrome Meeting. Eur J Endocrinol 2017; 177: G1-G70. doi: 10.1530/ EJE-17-0430 